\title{
ЗАБЕЗПЕЧЕННЯ ЕКОЛОГІЧНОЇ БЕЗПЕКИ В АГРАРНОМУ СЕКТОРІ
}

Статтю присвячено обтрунтуванню теоретико-методологічних і методичних засад забезпечення екологічної безпеки аграрного сектору. Розкрито сутність спільної аграрної політики, що полягає у регулюванні розміру відповідальності за збереження довкілля, відповідність виробничої діяльності встановленим стандартам, щзо забезпечує сталий розвиток сільських територій. Обтрунтовано, щзо європейська практика регулювання аграрної економіки, яка заснована на програмно-цільовому методі, визначає основні напрями діяльності у сфері охорони навколишнього природного середовища в сільському господарстві через програмні документи. Висвітлено світовий досвід управління екологоекономічною безпекою аграрного сектору, окреслено можливості застосування зарубіжного досвіду забезпечення екологічної безпеки у вітчизняних реаліях, запропоновано використання моніторингу як інструменту управління еколого-економічною безпекою аграрного сектору. Встановлено основні иілі аграрної політики у сфері забезпечення екологічної безпеки, щуо відповідають стратегічним пріоритетам. Сформульовано сукупність пропозищій щзодо змічнення екологічної безпеки аграрного сектору України. Встановлено, щзо стратегія забезпечення екологічної безпеки в аграрному секторі та інструменти стратегічного управління у иій сфері мають передбачати врахування певних етапів. Проведено аналіз забезпечення стратегічного розвитку аграрного сектора на національному та міжнародному рівні, щзо свідчть про необхідність створення принципово нової системи нормативноправових актів, щзо регулюють екологічну безпеку в аграрній сфері. Охарактеризовано чинники, що перешкоджають екологізації агровиробництва. Обтрунтовано, щзо нинішня аграрна політика держави має враховувати пріоритети забезпечення екологічної безпеки і в процесі ї реалізації трунтуватися на єдиному підході до забезпечення раціонального природокористування та охорони довкілля в сільському господарстві.

Ключові слова: екологічна безпека, аграрний сектор, сутність, парадигма, забезпечення, агроекосистема.

О.Г. КАРТАШОВА

Херсонский государственный аграрно-экономический университет ORCID: 0000-0002-9692-7032

\section{ОБЕСПЕЧЕНИЕ ЭКОЛОГИЧЕСКОЙ БЕЗОПАСНОСТИ В АГРАРНОМ СЕКТОРЕ}

Статья посвящена обоснованию теоретико-методологических и методических основ обеспечения экологической безопасности аграрного сектора. Раскрыта сущность совместной аграрной политики, заключающейся в регулировании размера ответственности за сохранение окружающей среды, соответствие производственной деятельности установленным стандартам, обеспечивает устойчивое развитие сельских территорий. Обосновано, что европейская практика регулирования аграрной экономики, основанной на программно-целевом методе, определяет основные направления деятельности в области охрань окружающей природной среды в сельском хозяйстве через программные документы. Освещены мировой опыт управления эколого-экономической безопасностью аграрного сектора, определены возможности применения зарубежного опыта обеспечения экологической безопасности в отечественных реалиях, предложено использование мониторинга как инструмента управления эколого-экономической безопасностью аграрного сектора. Установлень основные иели аграрной политики в сфере обеспечения экологической безопасности, соответствующие стратегическим приоритетам. Сформулированы совокупность предложений по укреплению экологической безопасности аграрного сектора Украины. Установлено, что стратегия обеспечения экологической безопасности в аграрном секторе и инструменты стратегического управления 6 этой сфере должны предусматривать учета определенных этапов. Проведен анализ обеспечения стратегического развития аграрного сектора на национальном и международном уровне, что свидетельствует о необходимости создания принципиально новой системы нормативно-правовых актов, регулирующих экологическую безопасность в аграрной сфере. Охарактеризованы факторы, препятствующие экологизации агропроизводства. Обосновано, что нынешняя аграрная политика государства должна учитывать приоритеты обеспечения экологической безопасности и в прочессе ее реализации основываться на едином подходе к обеспечению рачионального природопользования и охрань окружающей среды в сельском хозяйстве. 
Ключевые слова: экологическая безопасность, аграрный сектор, сущность, парадигма, обеспечения, агроэкосистема.

O.KARTASHOVA,

Kherson State agrarian and economic University ORCID: 0000-0002-9692-7032

\section{ENSURING ENVIRONMENTAL SAFETY IN THE AGRICULTURAL SECTOR}

The article is devoted to substantiation of theoretical-methodological and methodical bases of maintenance of ecological safety of agrarian sector. The essence of the common agricultural policy is revealed, which consists in regulating the amount of responsibility for environmental protection, compliance of production activities with the established standards, which ensures sustainable development of rural areas. It is substantiated that the European practice of regulation of agrarian economy, which is based on the programtarget method, determines the main directions of activity in the field of environmental protection in agriculture through program documents. The world experience of management of ecological and economic safety of agrarian sector is covered, possibilities of application of foreign experience of maintenance of ecological safety in domestic realities are outlined, use of monitoring as the tool of management of ecological and economic safety of agrarian sector is offered. The main goals of agricultural policy in the field of environmental security, which correspond to strategic priorities, have been established. A set of proposals for strengthening the environmental safety of the agricultural sector of Ukraine has been formulated. It is established that the strategy of ensuring environmental safety in the agricultural sector and the tools of strategic management in this area should take into account certain stages. An analysis of the strategic development of the agricultural sector at the national and international levels, which indicates the need to create a fundamentally new system of regulations governing environmental safety in the agricultural sector. Factors that prevent the greening of agricultural production are described. It is substantiated that the current agrarian policy of the state should take into account the priorities of environmental safety and in the process of its implementation should be based on a unified approach to ensuring the rational use of nature and environmental protection in agriculture.

Key words: ecological safety, agrarian sector, essence, paradigm, maintenance, agroecosystem.

\section{Постановка проблеми}

Аграрна політика задає загальну цільову орієнтацію в аспекті реалізації функцій держави щодо розв'язання актуальних проблем у галузі сільськогосподарського природокористування і забезпечення екологічної безпеки зокрема. Для досягнення сталого розвитку сільського господарства і послідовної реалізації аграрної політики необхідним є визначення серед пріоритетів екологічно-збалансований розвиток аграрного сектора економіки. Існуюча державна політика агровиробництва в Україні не передбачає комплексного підходу до розв’язання екологічних та соціально-економічних проблем. Тому включення до нормативно-правових актів положень, що закріплюють принципи сталого розвитку до стратегічних основ державної аграрної політики є передумовою єдиного підходу до реалізації раціонального природокористування та забезпечення охорони навколишнього природного середовища в агросфері.

Аналіз останніх досліджень і публікацій

Теоретико-методичні засади забезпечення екологічної безпеки були досліджені науковцями С.M. Ілляшенка, О.П. Литвином, Г.О. Обиход, В.Г. Потапенком, О.В. Прокопенком, С.М. Рогач, М.С. Самойлік , Л.І. Соломенко, Шкуратовим О. І.. Поряд із тим, не зважаючи на велику кількість наукових праць 3 дослідження питань екологічної безпеки, наукове обгрунтування сутності та концептуальних засад цього поняття з урахуванням специфіки сільського господарства залишається недостатньо глибоко дослідженим.

\section{Формулювання мети дослідження}

Метою статті $є$ дослідження сутності екологічної безпеки та визначення нормативного та економічного змісту явища в аграрному секторі економіки.

\section{Викладення основного матеріалу дослідження}

Свропейська практика регулювання аграрної економіки, яка заснована на програмно-цільовому методі, визначає основні напрями діяльності у сфері охорони навколишнього природного середовища в сільському господарстві через програмні документи. До основоположних документів ЄС у цій сфері відносяться програми, що є складовими Спільної аграрної політики ЄС (САП) та Загальної програми дій Союзу з охорони навколишнього середовища до 2020 р. «Жити добре в рамках обмеженості ресурсів нашої планети» [1]. Загалом, на сьогодні САП - це політика, яка регулює розмір відповідальності за збереження довкілля, відповідність виробничої діяльності встановленим стандартам, що забезпечує сталий розвиток сільських територій. Поява основного напряму САП, який виражається в комплексному підході до співвідношення між фінансовою підтримкою та стандартами охорони навколишнього 
природного середовища, якості та безпеки продуктів харчування, бере свій початок у 2004 р. [2]. Охорона навколишнього природного середовища була визнана необхідною складовою господарської діяльності завдяки прийняттю «Порядку денного 2000» (Agenda, 2000), а сталий розвиток - невід'ємним iї компонентом. Основна мета САП - створення екологічно безпечної та високоякісної продукції одночасно зі збереженням стану довкілля завдяки орієнтації на відновлювальні ресурси. До завдань розвитку та реформування САП відносять впровадження принципів збалансованого управління та раціонального використання природних ресурсів у процесі сільськогосподарського виробництва [3; 4]. Здійнення вищезазначених програм передбачають функціонування стимулюючих механізмів впровадження принципів сталого розвитку в сільськогосподарську діяльність за допомогою застосування всіх можливостей державної політики для забезпечення екологічно орієнтованого агровиробництва. До головних інструментів САП належать виплати у вигляді субсидій суб'єктам господарювання, які впроваджують екологічно безпечні способи виробництва, тим самим реалізуючи принципи охорони навколишнього природного середовища. Опираючись на спільну аграрну політику Європейського Союзу, кожна держава формує власну екологічну політику.

В Україні прийнято низку програм, які закріплюють основу раціонального природокористування в сільському господарстві, основною 3 яких $є$ Державна цільова програма розвитку аграрного сектору економіки на період до 2022 року [5]. Також, чинні положення державної політики у сфері охорони довкілля визначені екологічним законодавством та $є$ основою взаємозв'язків між державними органами та міжнародними організаціями, органами місцевого самоврядування і сільськогосподарськими об’єднаннями щодо забезпечення спільного вирішення питань збалансованого природокористування та охорони навколишнього середовища за допомогою комплексного підходу [6]. Разом з тим, є очевидним, що сучасні умови господарювання в аграрному секторі економіки потребують не стільки вдосконалення існуючих на сьогодні стратегій екологічної політики, скільки перенесення процесів екологізації в діючу аграрну політику. Нинішня аграрна політика держави має враховувати пріоритети забезпечення екологічної безпеки і в процесі iï реалізації грунтуватися на єдиному підході до забезпечення раціонального природокористування та охорони довкілля в сільському господарстві. $€$ важливим забезпечити необхідну ув'язку концептуальних і програмних розробок щодо забезпечення екологічної безпеки 3 існуючими концепціями і програмами соціально-економічного розвитку, програмами 3 охорони навколишнього природного середовища та іншими матеріалами. Гостра необхідність реалізації збалансованого природокористування та забезпечення екологічної безпеки в процесі здійснення сільськогосподарської діяльності $є$ вагомим аргументом на користь формування та впровадження уніфікованого комплексного нормативного документа, який має об'єднати в один законодавчий акт існуючі положення, які регулюють всі аспекти екологізації аграрних відносин [7 ].

Екологічна безпека аграрного сектора може бути досягнута, якщо будуть визначені найважливіші стратегічні напрями їі забезпечення у рамках цієї доктрини, побудована чітка логічна схема своєчасного виявлення та ліквідації можливих небезпек і загроз, зменшення наслідків [7 ; 8]. Для цього необхідно, щоб найважливішою частиною системи управління екологічною безпекою стали прогнозно-аналітичні документи, а саме, стратегія та програма екологічної безпеки в аграрному секторі, які повинні стати інструментом реалізації екологічної політики в Україні та регіонах. Загалом, співвідношення розглянутих документів можна представити схематично (рис. 1).

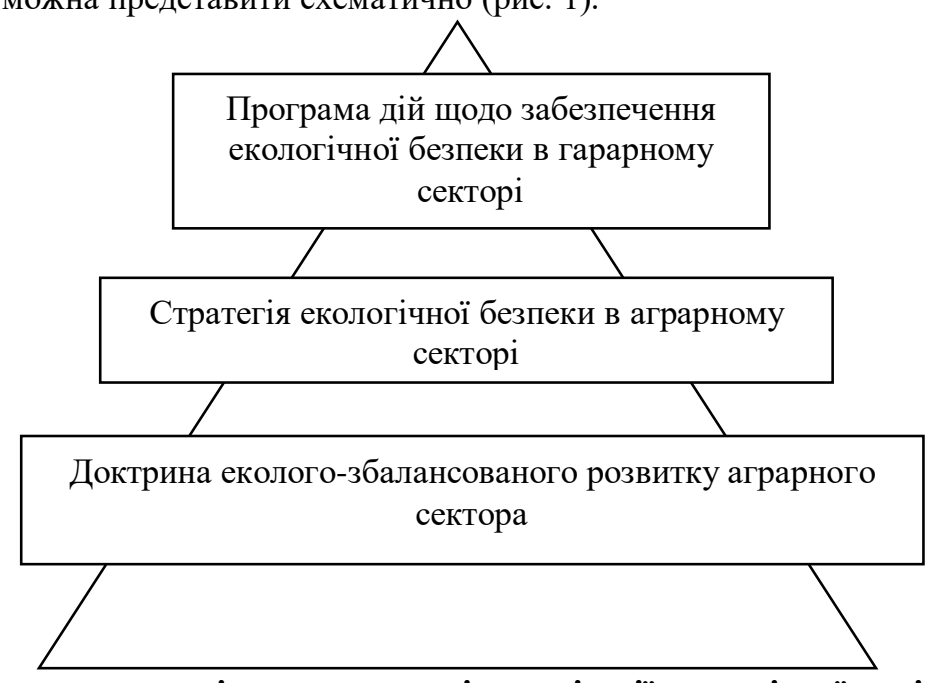
секторі

Рис.1 Співвідношення стратегічних документів реалізації екологічної політики в аграрному

Таким чином, аналіз забезпечення стратегічного розвитку аграрного сектора на національному та міжнародному рівні свідчить про необхідність створення принципово нової системи нормативно- 
правових актів, що регулюють екологічну безпеку в аграрній сфері. 3 огляду на зазначене, актуалізації набирає прийняття Закону України «Про сталий розвиток аграрного сектора України», який буде основним законодавчим актом, що регламентуватиме аграрні відносини, спрямовані на сталий розвиток сільського господарства та стане доктриною екологічно-збалансованого розвитку в аграрному секторі. Оскільки забезпечення екологічної безпеки в аграрному секторі $є$ одним 3 напрямів діяльності щодо забезпечення національної безпеки в цілому, до пропонованого закону має бути включені положення щодо питань охорони навколишнього природного середовища і забезпечення екологічної безпеки при здійсненні сільськогосподарської діяльності. Важливим кроком відпрацювання основних шляхів структурної трансформації аграрної економіки та розміщення продуктивних сил, що враховують імперативи збалансованого розвитку та забезпечення екологічної безпеки в агросфері $\epsilon$ розробка Стратегії екологічної безпеки в аграрному секторі, яка має включити сукупність найбільш значущих рішень, спрямованих на забезпечення програмного рівня безпеки та стати базовим документом стратегічного планування у сфері розвитку системи забезпечення екологічної безпеки в аграрному секторі і визначає комплекс взаємопов'язаних пріоритетів, цілей, завдань і заходів.

Відповідно до стратегічних пріоритетів, основними цілями аграрної політики у сфері забезпечення екологічної безпеки має бути: формування і забезпечення сталого стану агроекосистем, достатнього для сприятливих умов життєдіяльності людини та ведення сільськогосподарської діяльності в умовах техногенного навантаження на довкілля і впливу на нього різноманітних природних чинників; формування та розвиток системи збалансованого природокористування, що надає можливість забезпечити суспільство всіма видами необхідних природних ресурсів.

Однією з найважливіших передумов ефективності та дієвості системи забезпечення екологічної безпеки в аграрному секторі є вибір стратегічного курсу, який забезпечуватиме досягнення головної мети цієї системи - стійкого рівня екологічної безпеки. Необхідність формування та вибору стратегій забезпечення екологічної безпеки детермінується економічними реаліями сьогодення нашої держави. Адже відсутність на загальнодержавному та регіональному рівнях виваженого стратегічного курсу забезпечення екологічної безпеки, спрямованого на запобігання виникненню дестабілізуючих природну рівновагу чинників, зумовили хаотичність, непослідовність, низьку ефективність екологічної політики, та призвели до загрозливого і небезпечного стану довкілля багатьох регіонів держави [9; 10 ].

Формування будь-якої стратегії $\epsilon$ процесом, який має проходити певні етапи. Стратегія забезпечення екологічної безпеки в аграрному секторі та інструменти стратегічного управління у цій сфері мають передбачати врахування певних етапів:

1. Ідентифікація загроз та ризиків екологічної безпеки;

2. Діагностика рівня екологічної безпеки;

3. Оцінка впливу загроз та ризиків на рівень екологічної безпеки з урахуванням асиміляційного потенціалу;

4. Прогнозування сценаріїв екологічної безпеки;

5. Вибір стратегії управління екологічною безпекою в аграрному секторі;

6. Оцінка ефективності обраної стратегії управління екологічною безпекою та контроль за їі реалізацією.

В умовах ринкової економіки, визначальна роль в процесі формування та реалізації засад екологічної безпеки відводиться державним органам, оскільки суб'єкти господарювання намагаються уникати здійснення тих витрат, які не приносять їм відповідного доходу. Проте, держава 3 метою заощадження власних ресурсів, перекладає більшість таких витрат на суб'єктів господарювання. В умовах визначення оптимальних природно-ресурсних пропорцій та можливостей комбінувати ресурси в різних поєднаннях при виробництві різних видів продукції, вони можуть вибирати альтернативні варіанти розвитку. Для ефективної реалізації засад екологічної безпеки, в суб'єктів господарювання повинне бути чітке розуміння: збільшення витрат на вирішення екологічних проблем дозволить в майбутньому підвищити ефективність виробництва та посилити конкурентні переваги. Саме такий підхід дозволить підвищити частку екологічно орієнтованих підприємств [11].

Збалансованість аграрного виробництва на основі його екологізації забезпечується внаслідок підвищення ефективності використання природно-ресурсного потенціалу шляхом підтримки і активізації природних процесів в агроекосистемах. Визначальною умовою при цьому є розширене відтворення грунтової родючості і підвищення ефективності виробництва через максимальне задіяння біологічних факторів при раціональному використанні природних ресурсів. Це зумовлює модернізацію не лише структури витрат, а й перегляду всієї екологічної політики, реалізацію нових методів регулювання, комплексного підходу до екологізації сільськогосподарського виробництва, врахування екологічних ризиків в плануванні господарської діяльності. Протиріччя між економічною доцільністю та екологічною безпекою вимагають перегляду концепції розвитку аграрного сектора економіки, що й викликає необхідність розробки природоохоронних стратегій, орієнтованих на узгоджене вирішення економічних і екологічних проблем в аграрних підприємствах. 
Вирішення даного питання можливе за рахунок розвитку аграрного виробництва, заснованого на екологічному менеджменті, який в аграрному секторі економіки являє собою системний тип управління, орієнтований на формування та розвиток екологічно збалансованого сільськогосподарського виробництва 3 урахуванням багатофункціонального характеру природокористування в агросфері. Він повинен бути побудований на гармонійних еколого-економічних взаєминах.

На сучасному етапі розвитку аграрного сектора економіки ступінь продовольчої та екологічної безпеки істотно обумовлено альтернативними технологіями в галузі сільського господарства та збереженням природних ресурсів агросфери. Нині серед таких систем найбільший розвиток отримало органічне сільське господарство, що практикується на комерційному рівні в багатьох країнах світу. За визначенням Міжнародної федерації рухів органічного сільського господарства (IFOAM): «Органічне сільське господарство - виробнича система, що підтримує здоров'я грунтів, екосистем і людей» [7]. Це залежить від екологічних процесів, біологічної різноманітності та природних циклів, характерних для місцевих умов, коли не використовуються шкідливі ресурси, які можуть чинити несприятливі наслідки.

Згідно 3 правилами ведення органічного сільського господарства воно має грунтуватись на таких принципах: здоров'я (органічне сільське господарство повинно підтримувати й поліпшувати оздоровлення грунту, рослин, тварин, людини та планети як єдиного й неподільного цілого); екології (органічне сільське господарство повинне грунтуватися на живих екологічних системах і циклах, працювати, співіснувати 3 ними й підтримуючи їх); справедливості (органічне сільське господарство повинне будуватися на відносинах, що гарантують справедливість із урахуванням загального стану навколишнього природного середовища й життєвих можливостей); турботи (управління органічним сільським господарством повинне мати запобіжний і відповідальний характер і бути орієнтованим на захист здоров'я та добробуту нинішніх, майбутніх поколінь і навколишнього природного середовища).

Органічне сільське господарство надає можливість узгодити i гармонізувати екологічні, економічні та соціальні цілі в аграрному секторі економіки. Зокрема до переваг виробництва органічної сільськогосподарської продукції можна віднести: мінімізацію негативного впливу на довкілля; незалежність від мінеральних добрив i пестицидів та їх виробників, i як наслідок зменшення енергоємності національної економіки; створення додаткових робочих місць у сільській місцевості, перспектив для фермерських господарств; виробництво корисних, біологічно повноцінних та екологічно безпечних продуктів харчування. Органічне сільське господарство за своєю суттю можна визначити як цілісну систему управління агроекосистемами, що включає оцінку екологічних загроз та ризиків екологічній безпеці в аграрній сфері та встановлює порядок взаємовідносин економічних суб'єктів у процесі виробництва органічної сільськогосподарської продукції. При цьому концепція органічного сільського господарства полягає в тому, щоб якомога точніше повторити «виробництво» в природних агроекосистемах, спираючись на екологічні процеси, біорізноманіття та, адаптовано до економічних умов, поєднати в собі традиції, інновації і досягнення науки на благо навколишнього природного середовища та поліпшення якості життя всіх учасників.

Нині в Україні існує значний потенціал для розвитку органічного сільського господарства. Еколого-економічний аналіз сучасного стану виробництва органічної сільськогосподарської продукції свідчить про поступовість його розвитку, а саме: збільшення сертифікованих площ, підвищення внутрішнього споживчого ринку, підвищення обсягів реалізації виробленої продукції. Так, за даними Мінекономіки, у 2019 році загальна площа сільськогосподарських земель 3 органічним статусом та перехідного періоду склала близько 468 тис. га (1,1% від загальної площі земель сільськогосподарського призначення України). При цьому нараховувалось 617 операторів органічного ринку, з них 470 сільськогосподарські виробники [12]. Україна займає 20-те місце у світі і 11-те у Європі по площі земель, зайнятих під органічне сільськогосподарське виробництво. Наразі Україна посідає друге місце за обсягами експорту органічної продукції до $\mathrm{CC} \mathrm{і} \mathrm{цей} \mathrm{ринок} \mathrm{продовжує} \mathrm{активно} \mathrm{розвиватися} \mathrm{у} \mathrm{всьому}$ світі. Експортоорієнтованість органічного виробництва в Україні на ринки ЄС зумовлює досягнення рівнозначності у правовому регулюванні органічного виробництва та обігу органічної продукції та напрацювання національних особливостей в регулюванні у цій сфері.

\section{Висновки}

Стратегічною метою розвитку органічного сектора вітчизняної економіки визначено реалізація основних напрямів державної політики розвитку органічного сільського господарства, спрямованих на забезпечення екологічної безпеки аграрного сектора економіки, підвищення якості сільськогосподарської продукції, збереження та поліпшення родючості грунтів, охорону навколишнього природного середовища та збереження біорізноманіття, створення сприятливих умов для збалансованого розвитку сільських територій.

\section{Список використаної літератури}

1. Соломенко Л.І., Драченко В.Л. Пошук критеріїв для визначення екологічної безпеки застосування пестицидів. Вісник Дніпропетровського державного аграрного університету. 2014. № 1. С. $23-27$. 
2. Самойлік М.С. Оцінка ризиків та загроз ресурсно-екологічній безпеці регіону Бизнес Інформ. 2014. №6. (436). С. 185-192.

3. Булах І.Г. Актуальні питання правового регулювання, охорони і використання земельних ресурсів у контексті вирішення проблеми збереження біорізноманіття. Південноукраїнський правничий часопис. 2012. № 3. С. 124-128.

4. Сергєєва Л.А. Еколого-гігієнічні основи попередження шкідливого впливу факторів навколишнього середовища на здоров'я населення (за допомогою антимутагенних заходів): автореф. дис... д-ра мед. наук: 14.02.01

5. Розпорядження Кабінету Міністрів України від 30 грудня 2015 р. № 1437-р «Про схвалення Концепції Державної цільової програми розвитку аграрного сектору економіки на період до 2022 року». [Електронний ресурс]: https://zakon.rada.gov.ua/laws/show/1437-2015-\%D1\%80\#Text

6. Закон України «Про охорону навколишнього природного середовища»: [Електронний ресурс] Офіційний сайт Верховної ради України: http://zakon2.rada.gov.ua/

7. Литвин О.П. Механізми державного управління у забезпечені екологічної безпеки. Науковий вісник Академії муніципального управління. Серія : Управління. 2012. Вип. 3. С. 102- 110.

8. Віленчук О.М. Особливості використання екологічного страхування в аграрному природокористуванні. Облік і фінанси АПК. 2005. № 8. С. 51-56.

9. Доклад Конференции Организации Объединенных Наций по окружающей среде и развитию (Рио-де-Жанейро, 3-14 июня 1992 год) Нью-Йорк, 1993. 520 с.

10. Рогач С.М. Інституціональні домінанти екологізації аграрного природокористування. Науковий вісник Національного університету біоресурсів і природокористування України. Сер. : Економіка, аграрний менеджмент, бізнес. 2013. Вип. 181(6). С. 194-201.

11. Обиход Г.О. Методичні підходи щодо оцінки рівня екологічної небезпеки регіонів України: Ефективна економіка. 2012. № 10. [Електронний ресурc]: http://www.economy.nayka.com.ua

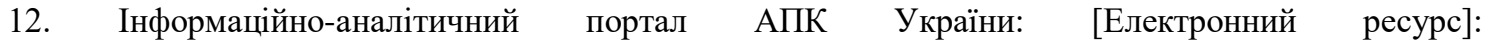
https://agro.me.gov.ua/ua/napryamki/organichne-virobnictvo/organichne-virobnictvo-v-ukrayin

13. Шкуратов O.I. Сутність екологічної безпеки в аграрному секторі економіки: теоретичні підходи. Агросвіт 15-16 (2017): 3-10.

1. Solomenko, L.I., Drachenko, V.L. (2014). Search for criteria for determining the environmental safety of pesticides. Bulletin of Dnipropetrovsk State Agrarian University, 1, 23-27.

2. Samoylik, M.S. (2014). Assessment of risks and threats to resource and environmental security of the region. Business Inform, 6. (436), 185-192.

3. Bulakh, I.G. (2012). Current issues of legal regulation, protection and use of land resources in the context of solving the problem of biodiversity conservation. South Ukrainian Law Journal, 3, 124-128.

4. Sergeeva, L.A. (1999). Ecological and hygienic bases of prevention of harmful influence of environmental factors on public health (by means of antimutagenic measures). (Dissertation of Dr. of Medical Sciences). Ukr. Science. hygiene. center. Kiev.

5. Order of the Cabinet of Ministers of Ukraine № 1437-r. (2015, December 30). About approval of the Concept of the State target program of development of agrarian sector of economy for the period till 2022. https://zakon.rada.gov.ua/laws/show/1437-2015-\%D1\%80\#Text

6. Law of Ukraine (1991). On environmental protection. Information of the Verkhovna Rada of Ukraine, (41), 1143-1173.

7. Litvin, O.P. (2012). Mechanisms of public administration in ensuring environmental safety. Scientific Bulletin of the Academy of Municipal Administration. Series: Management, 3, 102- 110.

8. Vilenchuk, O.M. (2005). Features of the use of environmental insurance in agricultural nature management. Accounting and finance of agro-industrial complex. 8, 51-56.

9. Koptyug, V.A. (1992). Conference UN environment and development. Rio de Janeiro, June, 1992-62.

10. Rogach, S.M. (2013). Institutional dominants of greening of agrarian nature management. Scientific Bulletin of the National University of Life and Environmental Sciences of Ukraine. Ser.: Economics, agricultural management, business. 181 (6), 194-201.

11. Obikhod, G.O., Omelyanenko, T.L. (2012). Methodical approaches to assessing the level of environmental danger in the regions of Ukraine. Efficient economy, 10.

12. Organic production in Ukraine. (2021, April 6). Information and Analytical Portal of the AIC of Ukraine. https://agro.me.gov.ua/ua/napryamki/organichne-virobnictvo/organichne-virobnictvo-v-ukrayini.

13. Shkuratov OI. The essence of environmental safety in the agricultural sector of the economy: theoretical approaches. Agrosvit 15-16 (2017): 3-10. 